\title{
Distribution of the species of Dipturus Rafinesque (Rajidae, Rajinae, Rajini) off Brazil and first record of the Caribbean skate D. teevani (Bigelow \& Schroeder), in the Western South Atlantic
}

\author{
Ulisses Leite Gomes ${ }^{1}$ \\ Simone da Silva Picado ${ }^{1}$
}

\begin{abstract}
The Caribbean skate Dipturus teevani (Bigelow \& Schroeder, 1951) is recorded for the first time from Brazilian waters. The specimen was collected in the continental slope off Bahia State. With this record, four species of Dipturus Rafinesque, 1810 are known from Brazil: $D$. chilensis (Guichenot, 1848), D. leptocauda (Kreft \& Stehmann, 1975), D. trachyderma (Krefft \& Stehmann, 1975) and D. teevani (Bigelow \& Schroeder, 1951). They are typical inhabitants of deep waters between the outer shelf edge $(195-200 \mathrm{~m})$ and the slope (more than $500 \mathrm{~m})$. Although morphologically conservative, the species of Dipturus can be distinguished from each other by the number of dorsal and nuchal thorns, the number of caudal thorns, dorsal and ventral spinulation and specific total length. An identification key for the species of Dipturus recorded from Brazil is presented.

KEY WORDS. Rajidae, Dipturus, distribution, Brazil
\end{abstract}

The genus Dipturus Rafinesque, 1810 consists of 29 species (MCEACHRAN \& DUNN 1998). They have a worldwide distribuition, except for the tropical eastern and North Pacific and are found from the continental shelf to archibenthal depths (STEHMANN 1970). The depth distribution of Dipturus species (MCEACHRAN \& MIYAKE 1990), varies from 25 to almost 1150m; in tropical waters, they are found generally over the continental slope. According to these authors, the genus is most diverse in the western North Atlantic, the southern African region, and the eastern North Atlantic.

The species of Dipturus are offshore skates, characterized by its dorsal and ventral dark colour (from dark brown to black), a proportionally elongated stiff snout, and a smooth skin with few tubercles (COMPAGNO et al. 1989; CHEN \& JOUNG 1989).

In Brazilian waters (western South Atlantic), Dipturus species are rare and poorly known. The thintail skate, D. leptocauda (Krefft \& Stehmann, 1975), was described based on a juvenile specimen, captured in 1968 over the continental slope in $500 \mathrm{~m}$ depth in southern Brazil.

1) Departamento de Biologia Animal e Vegetal, Instituto de Biologia, Universidade do Estado do Rio de Janeiro. Rua São Francisco Xavier 524, 20559-900 Rio de Janeiro, Rio de Janeiro, Brasil. E-mail: ulisses@uerj.br 
The yellownose skate, D. chilensis (Guichenot, 1848), (formerly known as Raja flavirostris Philippi, 1892) was first recorded from Brazilian waters by SADOWSKY (1973), in a list of cartilaginous fishes captured between Torres (Rio Grande do Sul, southern Brazil) and Maldonado (Uruguay).

VOOREN (1997), in a trawl survey of slope of Rio Grande do Sul (southwestern Atlantic), obtained two specimens, identified at the time as D. leptocauda. However Matthias Stehmann examined the specimens and identified them as the roughskin skate, D. trachyderma (Krefft \& Stehmann, 1975)(Vooren, pers. comm.). This ocurrence is the first record of the latter species in Brazil.

Recently, in July 1999, another Dipturus species was captured off Brazil, trawled over the continental slope by the French R.V. Thalassa. The specimen was identified as Dipturus teevani (Bigelow \& Schroeder, 1951), and represents a new record of the caribbean skate for Brazilian waters.

A discussion on the distribution of the Dipturus species which occur in Brazil, and a key for their identification, are the main objectives of the present study.

\section{MATERIAL AND METHODS}

The taxonomic classification follows MCEACHRAN \& DUNN (1998); measurements of $D$. teevani are modified from MENNI (1973). The terminology of the spinulation of Dipturus species is based on STEHMANN \& BÜRKEL (1984) and LEIBLE (1988) (Fig. 1). Specimens of the apparently rare Dipturus leptocauda were not examined (only the holotype is known). The species outlines are based on NORMAN (1937) for D. chilensis, KREFFT \& STEHMANN (1975) for both D. leptocauda and D. trachyderma, and BIGELOW \& SCHROEDER (1953) for D. teevani. The specimens examined are deposited in the following institutions: Departamento de Biologia Animal e Vegetal, Universidade do Estado do Rio de Janeiro (AC.DBAVUERJ [anatomical collection] and C.DBAVUERJ [ichthyological collection]); Museu Nacional do Rio de Janeiro (MNRJ); Museu de Zoologia da Universidade de São Paulo (MZUSP); Museu de Ciências e Tecnologia da Pontifícia Universidade Católica do Rio Grande do Sul, Porto Alegre (MCP); Fundação Universidade do Rio Grande, Rio Grande do Sul (FURG); and Museo Argentino de Ciencias Naturales "Bernardino Rivadavia", Buenos Aires (MACN).

\section{Material analysed}

Dipturus chilensis. C.DBAV.UERJ 1734, male, 493mm TL, 580mm DW, Argentina; MCP 3760, female, $195 \mathrm{~mm}$ TL, $144 \mathrm{~mm} \mathrm{DW}$, northern Uruguay and Argentina; MCP 3761 , male, $243 \mathrm{~mm}$ TL, $185 \mathrm{~mm}$ DW, northern Uruguay and Argentina; MCP 3757 , female, $320 \mathrm{~mm}$ TL, $235 \mathrm{~mm}$ DW, northern Uruguay and Argentina, MCP 3756 , female, $290 \mathrm{~mm}$ TL, $237 \mathrm{~mm} \mathrm{DW}$, northern Uruguay and Argentina; MCP 3759, male, $235 \mathrm{~mm}$ TL, $182 \mathrm{~mm}$ DW, northern Uruguay and Argentina; MCP 3751, female, 304mm TL, $235 \mathrm{~mm}$ DW, northern Uruguay and Argentina; MCP 3753 , female, $295 \mathrm{~mm}$ TL, $232 \mathrm{~mm}$ DW, northern Uruguay and Argentina; MCP 3758 , male, $322 \mathrm{~mm}$ TL, $245 \mathrm{~mm}$ DW, northern Uruguay and Argentina; MCP 3752 , female, $264 \mathrm{~mm}$ TL, $201 \mathrm{~mm} \mathrm{DW}$, northern Uruguay and Argentina; MACN 2885, male, $156 \mathrm{~mm} \mathrm{TL}, 117 \mathrm{~mm} \mathrm{DW}, 35^{\circ} 34^{\prime} \mathrm{S}, 52^{\circ} 48^{\prime} \mathrm{W}$; 


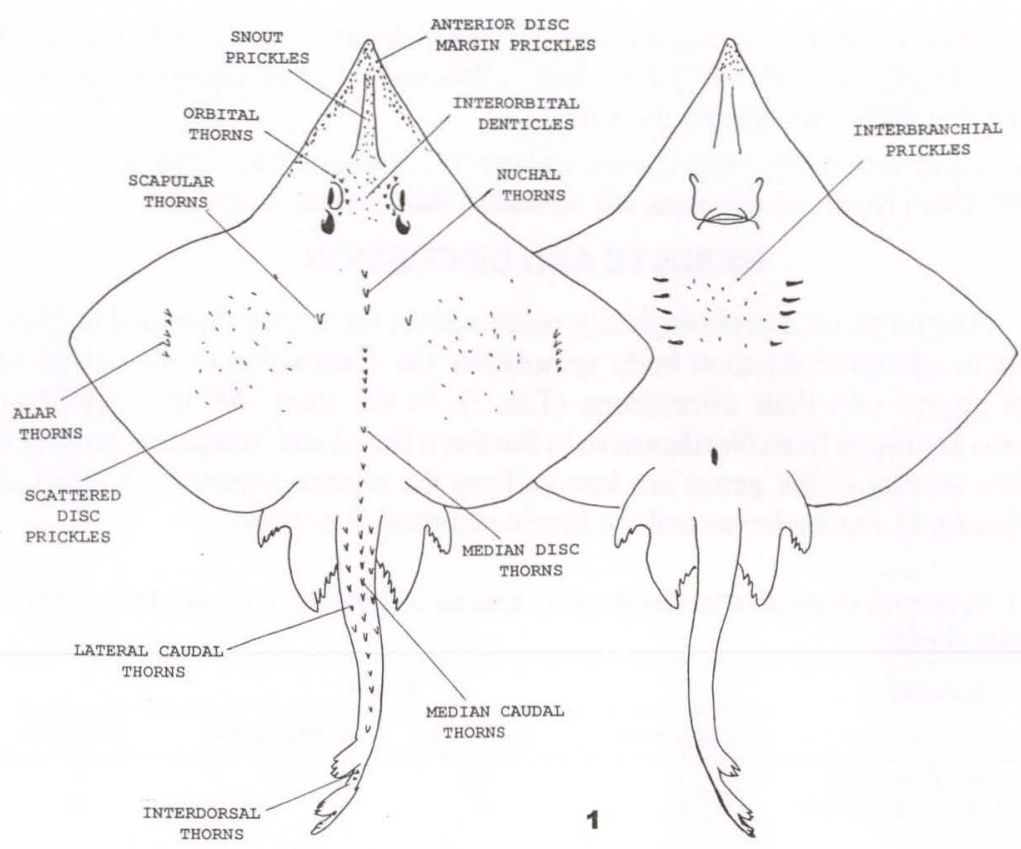

Fig. 1. Schematic diagram of the spinulation of Brazilian Dipturus species.

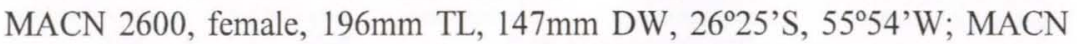
2600, female, $182 \mathrm{~mm}$ TL, $135 \mathrm{~mm}$ DW, $26^{\circ} 25^{\prime} \mathrm{S}, 52^{\circ} 54^{\prime} \mathrm{W}$; MACN 6035, female,307mm TL, $233 \mathrm{~mm}$ DW, Mar del Plata, Argentina; MACN 6035, male, $285 \mathrm{~mm}$ TL, $221 \mathrm{~mm}$ DW, Mar del Plata, Argentina; MACN 4365, female, $380 \mathrm{~mm}$ TL, $296 \mathrm{~mm}, 37^{\circ} 40^{\prime}$ to $38^{\circ} 04^{\prime} \mathrm{S}, 54^{\circ} 48^{\prime}$ to $55^{\circ} 15^{\prime} \mathrm{W}$; MACN 4365 , female, $370 \mathrm{~mm}$ TL, $287 \mathrm{~mm}$ DW, $37^{\circ} 40^{\prime}$ ' to $38^{\circ} 04^{\prime} \mathrm{S}, 54^{\circ} 48^{\prime}$ to $55^{\circ} 15^{\prime} \mathrm{W}$; MACN 4365 , female, $360 \mathrm{~mm}$ TL, $275 \mathrm{~mm} \mathrm{DW}, 37^{\circ} 40^{\prime}$ to $38^{\circ} 04^{\prime} \mathrm{S}, 54^{\circ} 48^{\prime}$ to $55^{\circ} 15^{\prime} \mathrm{W}$; MACN 4365 , male, $347 \mathrm{~mm} \mathrm{TL}, 261 \mathrm{~mm}$ DW $37^{\circ} 40^{\prime}$ to $38^{\circ} 04^{\prime} \mathrm{S}$, $54^{\circ} 48^{\prime}$ to $55^{\circ} 15^{\prime} \mathrm{W}$; MACN 569, female, $326 \mathrm{~mm}$ TL, $250 \mathrm{~mm}$ DW, Buenos Aires coast, Argentina; MACN 1334, male, $293 \mathrm{~mm}$ TL, $225 \mathrm{~mm} \mathrm{DW} ; 39^{\circ} 00 \mathrm{~S}, 56^{\circ} 00^{\prime} \mathrm{W}$; MACN 1500, male, 398mm TL, 316mm DW, Mar del Plata, Argentina; MACN 1500, male, $339 \mathrm{~mm}$ TL, 325 mm DW, Mar del Plata, Argentina; MACN 1500, male, 325mm TL, 254mm DW, Mar del Plata, Argentina; MACN 1500, male, $211 \mathrm{~mm}$ TL, $155 \mathrm{~mm}$ DW, Mar del Plata, Argentina; MACN 6162, female, $375 \mathrm{~mm}$ TL, $287 \mathrm{~mm} \mathrm{DW}, 38^{\circ} 20^{\prime} \mathrm{S}, 56^{\circ} 25^{\prime} \mathrm{W}$, Argentina.

Dipturus trachyderma. MZUSP 51600, male, $1510 \mathrm{~mm}$ TL, 1000mm DW, 2542'S, $45^{\circ} 08^{\prime} \mathrm{W}$, Rio de Janeiro, Brazil, depth $477 \mathrm{~m}$; MCP 17429 , male, $870 \mathrm{~mm}$ TL, $642 \mathrm{~mm}$ DW, Rio Grande do Sul, between Brazil and Uruguay coasts; FURG (18.IV.97), female, $1620 \mathrm{~mm}$ TL, $1205 \mathrm{~mm}$ DW, Rio Grande do Sul, Brazil; FURG EL 76, male, $971 \mathrm{~mm}$ TL, 740mm DW, Rio Grande, Brazil; AC.DBAVUERJ 1006 (head), sex, TL and DW unregistered, Rio Grande do Sul, Brazil; 
AC.DBAVUERJ 1007 (head), sex, TL and DW unregistered, Rio Grande do Sul, Brazil; AC.DBAVUERJ 1008, $1504 \mathrm{~mm}$ CT, LD unregistered, male, $23^{\circ} 17^{\prime}$ 'S $41^{\circ} 01^{\prime} \mathrm{W}$, São Paulo, Brazil.

Dipturus teevani. MNRJ 19233, male, $671 \mathrm{~mm}$ TL, $504 \mathrm{~mm} \mathrm{DW}, 13^{\circ} 40^{\prime} \mathrm{S} ; 38^{\circ} 71^{\prime} \mathrm{W}$, 450-500m (continental slope, off Salvador, Bahia State, Brazil).

\section{RESULTS AND DISCUSSION}

Despite being morphologically conservative, the species included in Dipturus can be identified by their body spinulation, the distribution of the nuchal and caudal thorns, and their dimensions (Tab. I). In the south Atlantic, species of Dipturus are found from Northeastern to Southern Brazil and in adjacent areas (Fig. 2 ). Four species of the genus are known from the region: Dipturus chilensis, $D$. leptocauda, D. trachyderma and the herein recorded D. teevani.

Table I. Distinctive characters for the Brazilian species of Dipturus. $(+)$ character present, $(0)$ character absent

\begin{tabular}{|c|c|c|c|c|}
\hline \multirow[t]{2}{*}{ Characters } & \multicolumn{4}{|c|}{ Species } \\
\hline & D. leptocauda & D. chilensis & D. trachyderma & D. teevani \\
\hline Number of caudal thorn rows & 1 & $1-3$ & 3 & 1 \\
\hline $\begin{array}{l}\text { Number of median thorn rows of } \\
\text { disc }\end{array}$ & 0 & 0 & 1 & 0 \\
\hline Interdorsal space & + & + & + & 0 \\
\hline Prickles along the snout & Only on snout apex & Only on snout apex & Along the snout & Only on snout apex \\
\hline $\begin{array}{l}\text { Space between } 2^{\text {nd }} \text { dorsal and } \\
\text { caudal fin }\end{array}$ & + & 0 & + & 0 \\
\hline $\begin{array}{l}\text { Distance from anus to caudal } \\
\text { apex, and to snout apex }\end{array}$ & $\begin{array}{l}\text { Anus in midway } \\
\text { between caudal } \\
\text { apex and snout apex }\end{array}$ & $\begin{array}{l}\text { Anus nearer caudal } \\
\text { apex than snout } \\
\text { apex }\end{array}$ & $\begin{array}{l}\text { Anus nearer caudal } \\
\text { apex than snout } \\
\text { apex }\end{array}$ & $\begin{array}{l}\text { Anus nearer caudal } \\
\text { apex than snout } \\
\text { apex }\end{array}$ \\
\hline Dorsal surface of the disc & Smooth & Smooth & Rough & $\begin{array}{l}\text { Smooth to touch (but } \\
\text { with tiny prickles) }\end{array}$ \\
\hline Ventral surface & Smooth & Smooth & Rough & Smooth \\
\hline $\begin{array}{l}\text { Interbranchial space with } \\
\text { scattered tiny prickles }\end{array}$ & + & 0 & + & 0 \\
\hline Preoral length in disc width & 3 times & 3,5 times & 3,5 times & 4,5 times \\
\hline Preoral length in disc length & 2,5 times & 3 times & 3 times & 3,5 times \\
\hline Mouth length in preoral length & 3 times & 2 times & 2,5 times & 2 times \\
\hline
\end{tabular}

\section{Dipturus chilensis}

Figs 2, 3, 7

Dipturus chilensis has a wide geographical range, occurring from Chile in the Pacific, all the way around southern South America to southern Rio Grande do Sul, in the Atlantic (Fig. 2). The holotype was collected at Bahia de Quinteros, Chile (EsCHMEYER et al. 1998). According to LeIBLE (1987) and LeIBLE et al. (1990), D. chilensis is recorded in Chile from $31^{\circ} 50^{\prime} \mathrm{S}, 73^{\circ} 45^{\prime} \mathrm{W}$ near Los Vilos, to Isla Mocha $\left(38^{\circ} 08 \mathrm{~S}^{\prime}, 73^{\circ} 45^{\prime} \mathrm{W}\right)$, in 60 to $1000 \mathrm{~m}$ depth.

Studying the Patagonian fishes, NoRMAN (1937) presented the distribution of this species as being: Chile, the Straits of Magellan, and from the PatagonianFalklands/Malvinas to Argentina (i.e. between $44^{\circ} 14^{\prime}$ 'S and $53^{\circ} 05^{\prime}$ 'S). In their study 
of the marine fishes of Patagonia, BELLISIO et al. (1979) affirm that $D$. chilensis is the most abundant skate captured in that region.

The Brazilian specimen was recorded from $33^{\circ} 47^{\prime} \mathrm{S}, 53^{\circ} 16^{\prime} \mathrm{W}$ (off Chuí, Rio Grande do Sul) (SADOWSKY 1973).

This species can be identified by a smooth dorsal surface with a single nuchal thorn, 1-3 caudal thorn rows (predomination of one row), a preoral length 3,5 times in disc width, and a mouth length two times in preoral length.

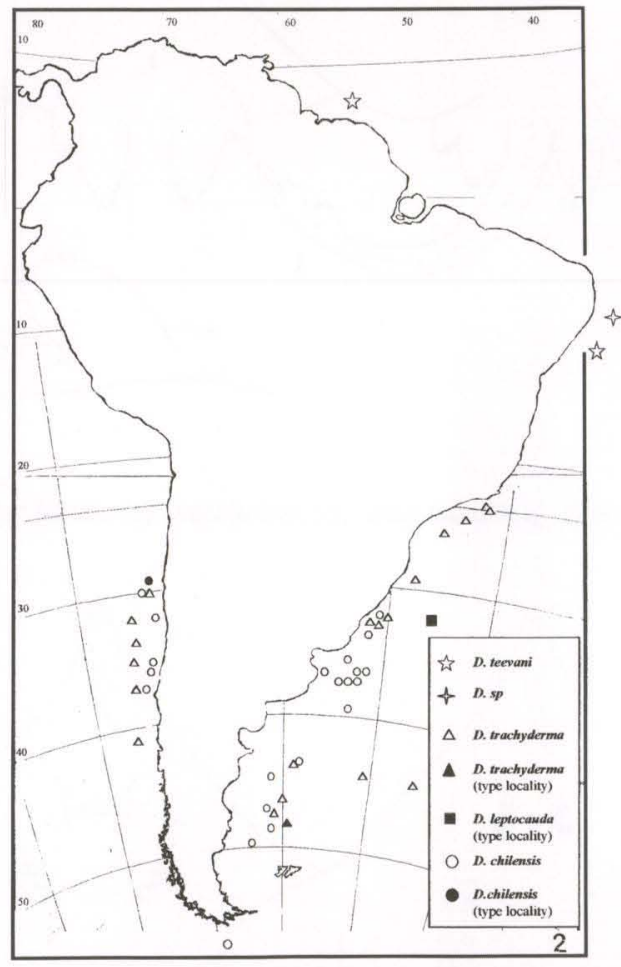

Fig. 2. Distribution of Dipturus chilensis, D. leptocauda, D. trachyderma, D. teevaniand Dipturus $s p$. in Brazilian waters and adjacent areas.

\section{Dipturus leptocauda}

Figs 2, 4

The type locality given by the authors reads "continental slope off Southern Brazil", at $24^{\circ} 21^{\prime} \mathrm{S}, 43^{\circ} 54^{\prime} \mathrm{W}$. Checking such co-ordinates, however it corresponds instead to the latitude of Rio de Janeiro, in southeastern Brazil (near Restinga de Marambaia), even though the research cruises of the FRV "Walther Herwig" to South America had its study area extending only from the south of Rio Grande do 


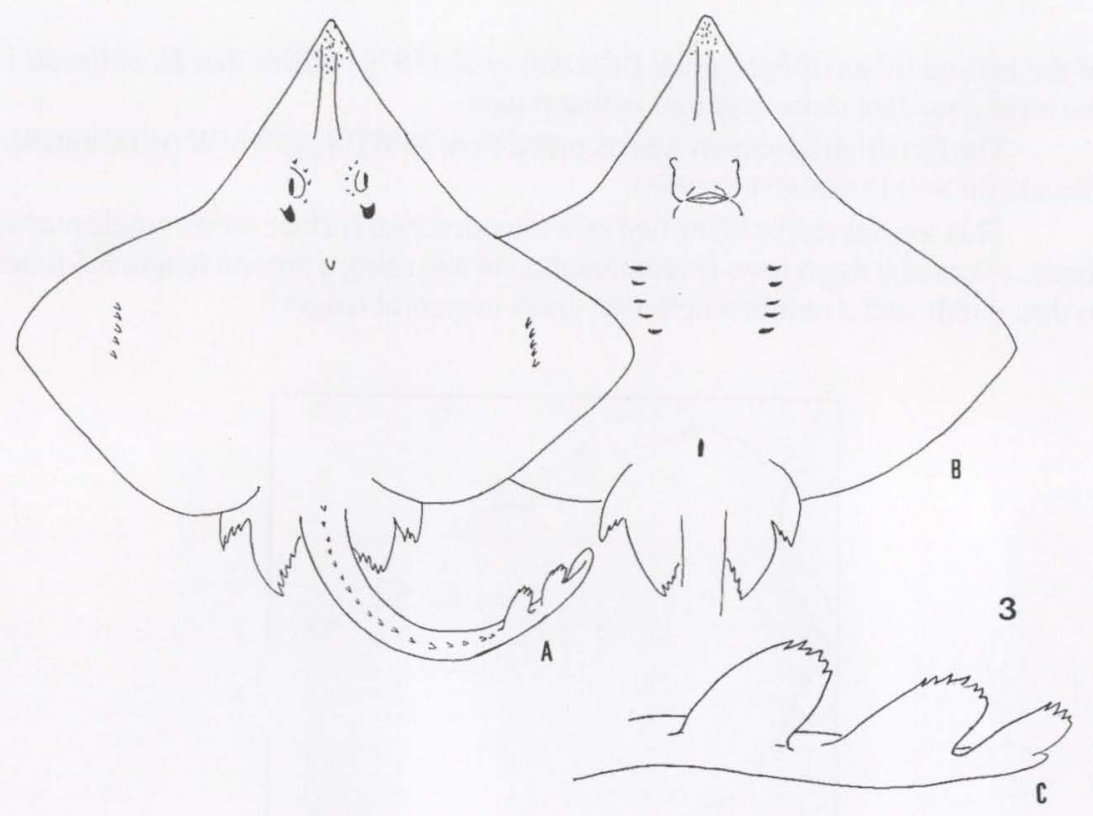

Fig. 3. Dipturus chilensis. (a) Dorsal view, (b) ventral view; (c) caudal region.

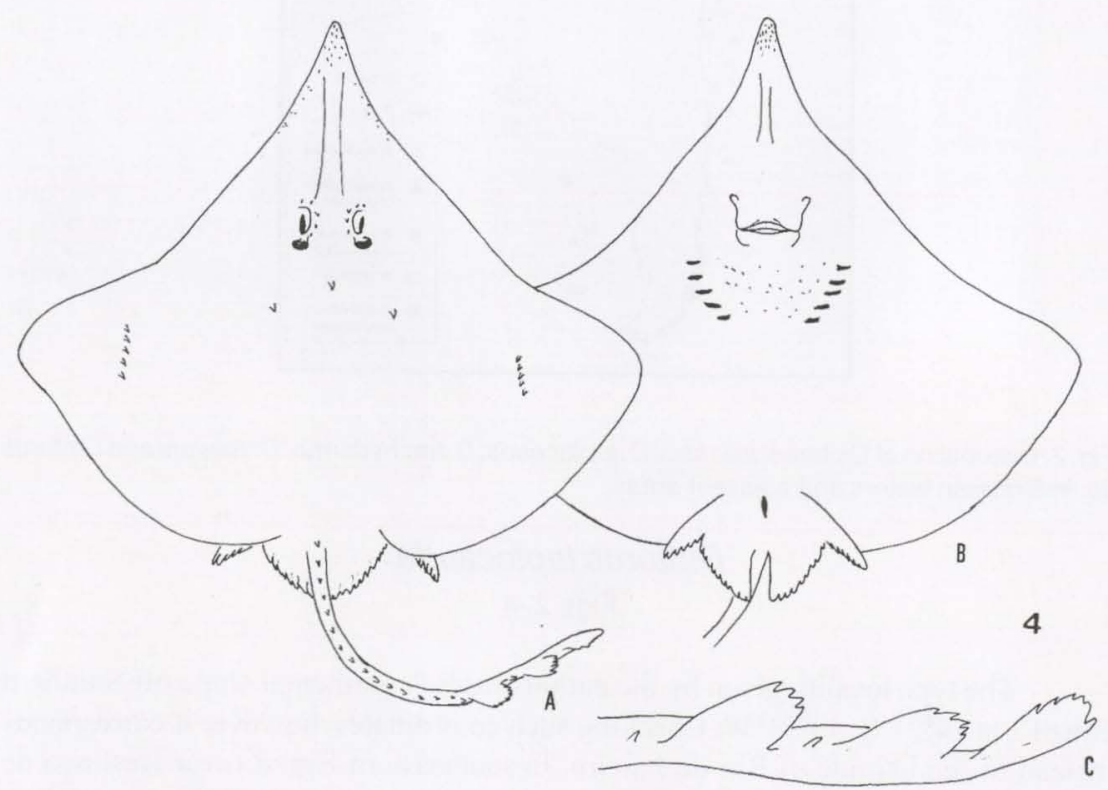

Fig. 4. Dipturus leptocauda. (a) Dorsal view, (b) ventral view; (c) caudal region. 
Sul, Brazil, to southern Argentina (KREFFT 1968; KREFFT \& STEHMANN 1975). It is supposed, therefore, that the co-ordinates given are in error, being thus the correct location of the type locality of $D$. leptocauda, $34^{\circ} 21^{\prime}$ 'S, $43^{\circ} 54^{\prime}$ 'W (i.e. off Rio Grande do Sul, Brazil).

Only a single specimen of $D$. leptocauda, the holotype, is known (Fig. 2). It is a young male of $479,5 \mathrm{~mm}$ TL. According to KREFFT \& STEHMANN (1975), this species can be identified by a single nuchal thorn, smooth dorsal surface of the disc, 16 predorsal thorns, one interdorsal thorn, and the anus in the midway between the apex of the caudal fin and the snout.

\section{Dipturus trachyderma}

Figs $2,5,8,9$

As D. chilensis, this species is found in the southern Pacific (off Chile), the Chilean Patagonian waters (Leible \& STEHMANN 1987), and southern Argentina (the holotype, $49^{\circ} \mathrm{S}, 60^{\circ} 52^{\prime} \mathrm{W}$ ) (KREFFT \& StEHMANN 1987) (Fig. 2). Additional Argentine specimens were recorded by MENNI \& GosZTONYI (1977) in the following co-ordinates: $47^{\circ} 36^{\prime} \mathrm{S}, 60^{\circ} 45^{\prime} \mathrm{W}$ and $49^{\circ} 05.5^{\prime} \mathrm{S}, 61^{\circ} 12^{\prime} \mathrm{W}$. Additional specimens collected in Argentina were taken in $45^{\circ} 30^{\prime} \mathrm{S}, 51^{\circ} 06^{\prime} \mathrm{S}$, and $46^{\circ} \mathrm{S}$ to $45^{\circ} 40^{\prime} \mathrm{S}$ on the Patagonian shelf, to the North of the type locality (LEIBLE \& STEHMANN 1987). Studying the fish associations in this region, MENNI \& GosZTONYI (1982) included $D$. trachyderma in what they called "ungrouped species", which were those characterized by being scarcely represented in the trawlings. In that region, $D$. trachyderma was captured along with the typical Magellanic species, such as the rajids Bathyraja scaphiops (Norman, 1937), B. multispinis (Norman, 1937) and Amblyraja doellojuradoi (Pozzi, 1935).

Studying the species composition of the demersal elasmobranchs in the southern Western Atlantic (Rio Grande do Sul), VOoREN (1997) recorded Dipturus leptocauda. This author (pers. comm.), in fact, was referring to Dipturus trachyderma. Other Brazilian records of D. trachyderma are from off southern São Paulo ( $\left.25^{\circ} 42^{\prime} \mathrm{S}, 45^{\circ} 08^{\prime} \mathrm{W}\right)$, and Rio de Janeiro ( $23^{\circ} 17^{\prime} \mathrm{S}, 41^{\circ} 01^{\prime} \mathrm{W}$, in $477 \mathrm{~m}$ depth). Still other records (Acácio Tomás, pers. comm.) of this species are: $32^{\circ} 10^{\prime} \mathrm{S}, 50^{\circ} 06^{\prime} \mathrm{W}$ (Rio Grande do Sul: depth 400m); $29^{\circ} 10^{\prime}$ S, $47^{\circ} 49^{\prime} \mathrm{W}$ (Rio Grande do Sul: depth

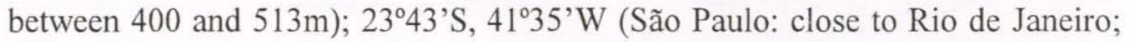
$259 \mathrm{~m}$ deep, figure 2). This specimen is deposited at the Instituto de Pesca, Santos, São Paulo, but not seen. According to VOOREN (1997), the species composition of southern demersal elasmobranchs includes permanent residents, winter or summer migrants, and sporadically occuring species. Dipturus trachyderma fits in the last group. It occurs in depths of 100 to $500 \mathrm{~m}$.

This species can be easily identified by the rough dorsal and ventral surfaces of the disc, and by the presence of small scattered denticles, specially on the interorbital region (Fig. 9). It is the largest Brazilian Dipturus, reaching more than $2000 \mathrm{~mm}$ of total length (LEIBLE \& STEHMANN 1987). 


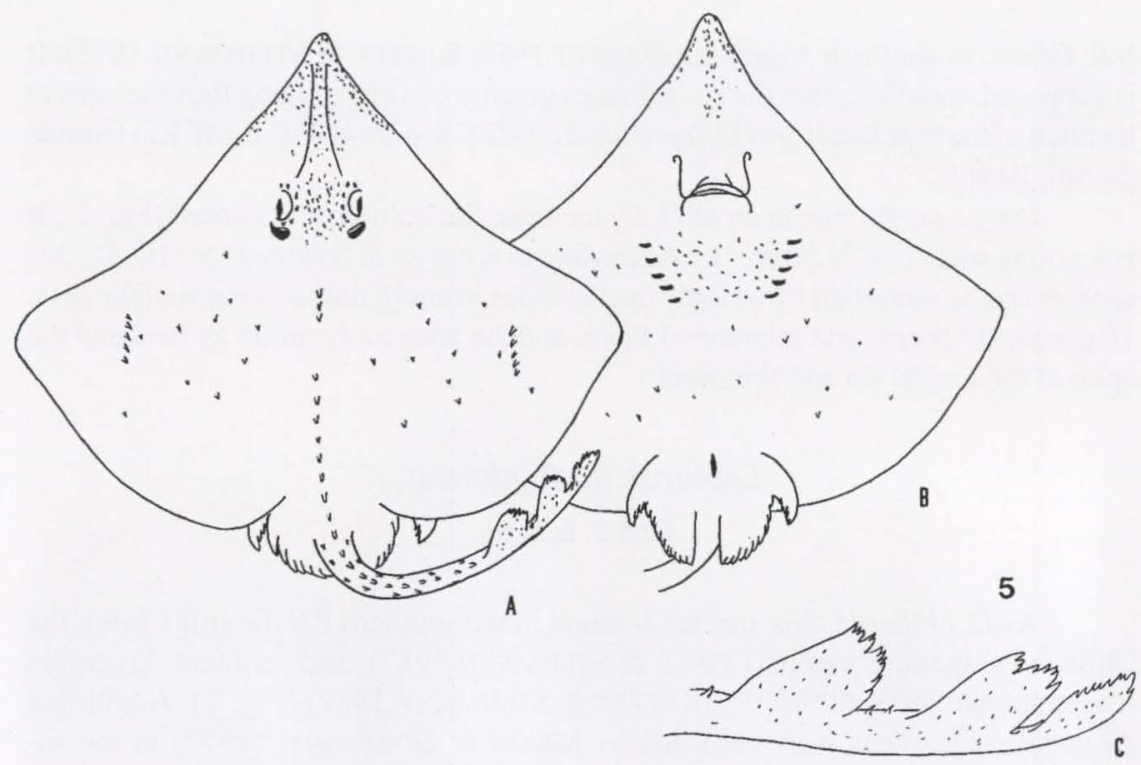

Fig. 5. Dipturus trachyderma. (a) Dorsal view, (b) ventral view, (c) caudal region.

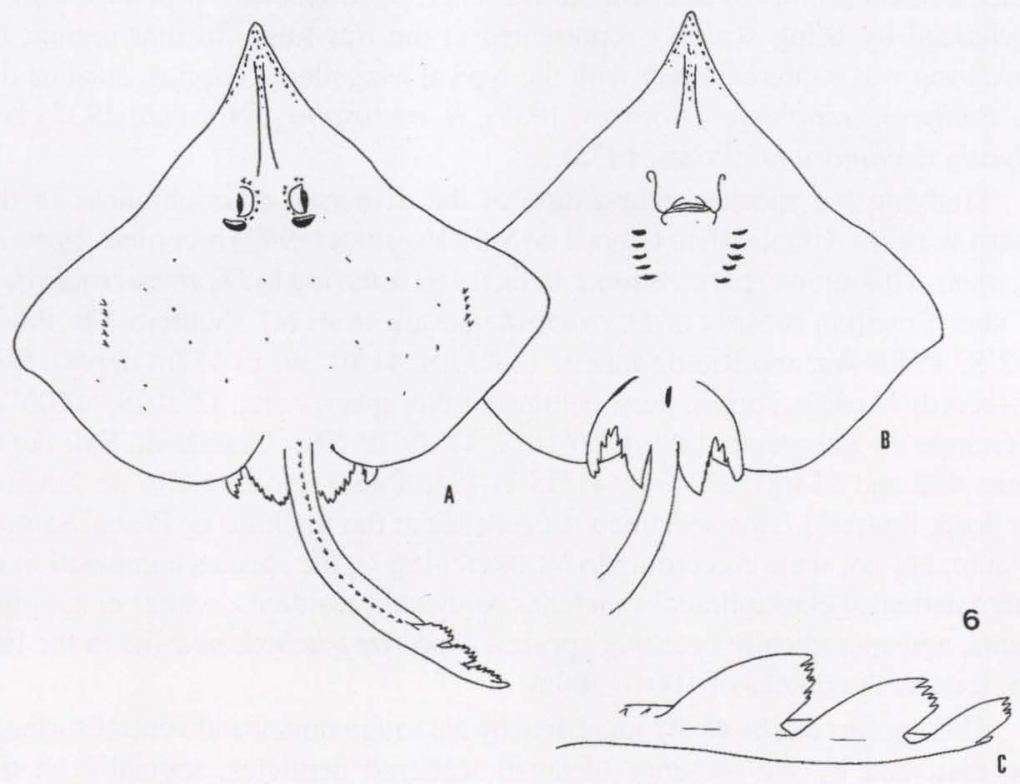

Fig. 6. Dipturus teevani. (a) Dorsal view, (b) ventral view, (c) caudal region. 


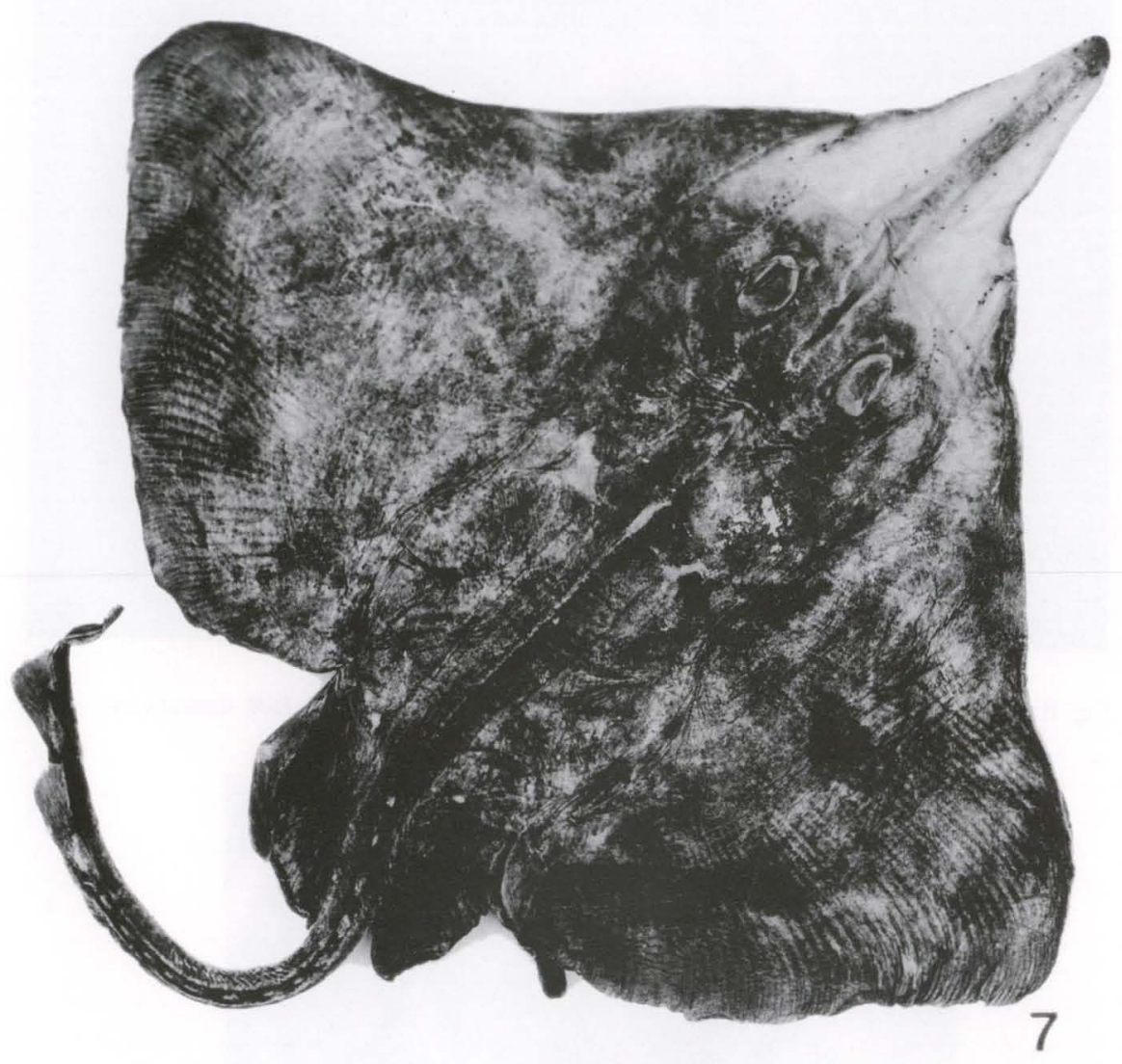

Fig. 7. Dipturus chilensis, C.DBAVUERJ 1734, male, 493mm TL, 580mm DW, dorsal view.

\section{Dipturus teevani}

Figs 2, 6, 10

The type specimen was caught off Pensacola, Florida, USA $\left(29^{\circ} 11^{\prime} \mathrm{N}\right.$, $85^{\circ} 32^{\prime} \mathrm{W}$ ), in 558m depth (BIGELOW \& SCHROEDER 1951). The species was later found off the Great Bahama Bank and Santaren Channel at a depth of 549 to $622 \mathrm{~m}$, and off the coasts of Honduras and Nicaragua, between $16^{\circ} 43^{\prime}$ and $12^{\circ} 25^{\prime} \mathrm{N}$ in $439-732 \mathrm{~m}$ depth (BIGELOW \& SCHROEDER 1965). UYENO \& MiYAKE (1983) also recorded five specimens of $D$. teevani from off Suriname at depths between $525-940 \mathrm{~m}$.

The single known Brazilian specimen was collected on July 7, 1999, off Salvador, Bahia State $\left(13^{\circ} 40^{\prime} \mathrm{S} ; 38^{\circ} 71^{\prime} \mathrm{W}\right)$ at a depth between $450-500 \mathrm{~m}$. The specimen represents the first record of $D$. teevani in Brazilian waters. 


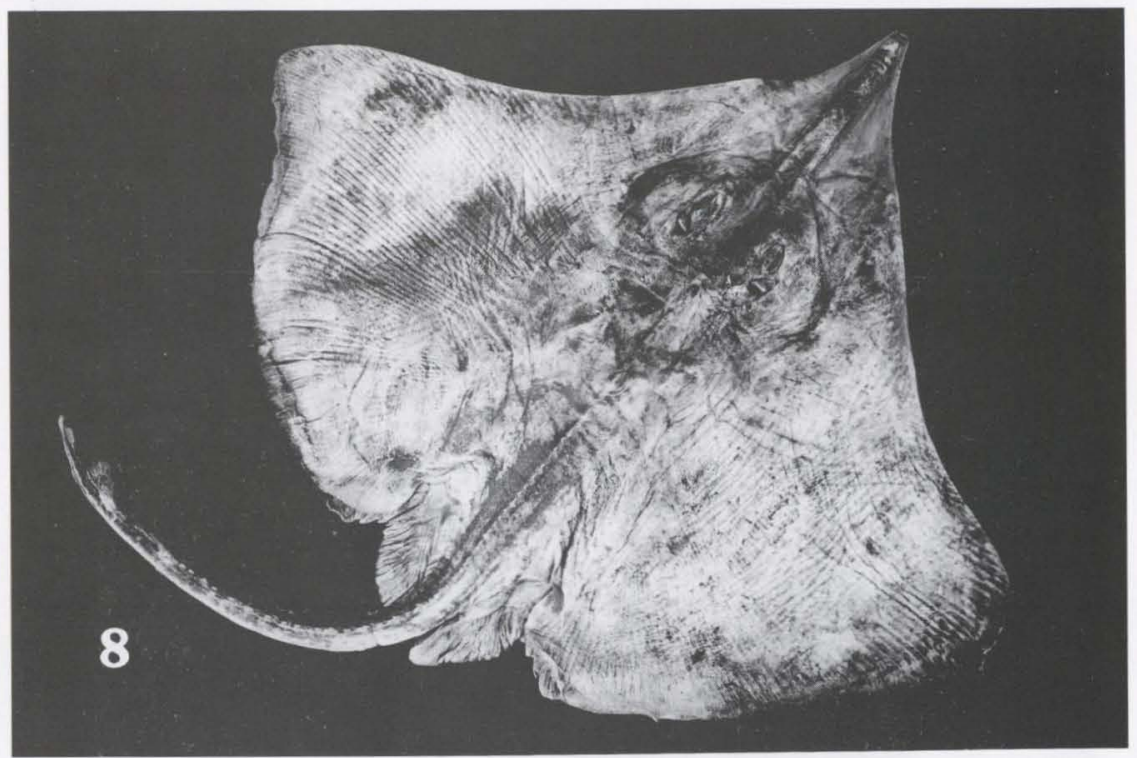

Fig. 8. Dipturus trachyderma, FURG EL 76, male, $971 \mathrm{~mm} \mathrm{TL,} \mathrm{740mm} \mathrm{DW,} \mathrm{dorsal} \mathrm{view.}$

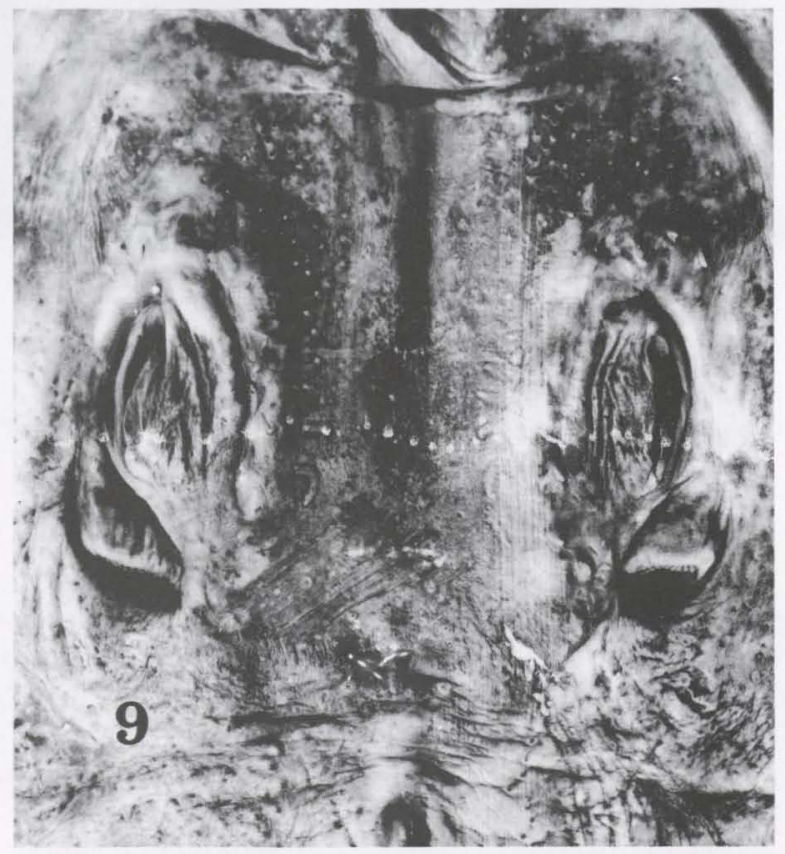

Fig. 9. Dipturus trachyderma, same specimen, detail of the inteorbital space. 


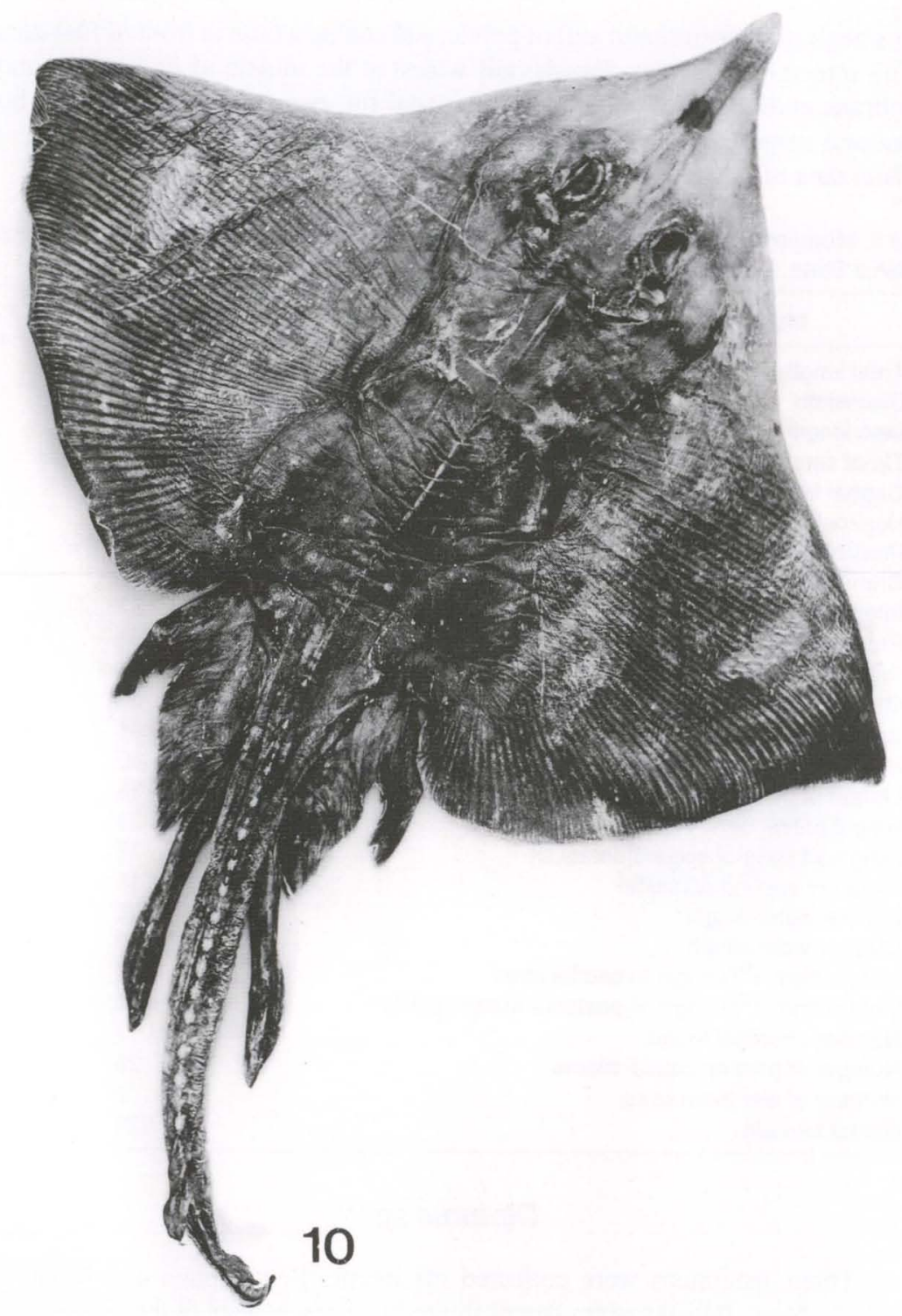

Fig. 10. Dipturus teevani, MNRJ 19233, male, $671 \mathrm{~mm}$ TL, 504mm DW.

Dipturus teevani is identified by the following characters as shown in BigelOW \& SCHROEDER (1951, 1953, 1965) and UYENO \& MiYAKE (1983): seven orbital thorns; no strong thorns anywhere on the dorsal surface (except on the tail region); minute prickles scattered over the entire disc; coarse prickles on snout and anterior margin of the disc; median row of the tail with 20 thorns; median caudal 
thorns beginning posterior to axil of pelvic, and ending a little in front of first dorsal fin; no interspace between dorsals; tail widest at the middle of its length; caudal membrane ending below the middle of caudal fin; two rows of alar thorns; both dorsal and ventral surfaces dark brown; dental formula 27/26. Morphometric and meristic data of the specimen are given in table II.

Table II. Morphometric and meristic data conducted of Dipturus teevani (adult male) collected off Bahia State. Measurements are expressed in milimeters.

\begin{tabular}{lr}
\hline \multicolumn{1}{c}{ Morphometric/meristic characters } & MNRJ 19233 \\
\hline Total length & 671 \\
Disc width & 504 \\
Disc length & 385 \\
Tip of snout to cloaca length & 350 \\
Caudal lenght & 270 \\
Horizontal eye diameter & 22 \\
Preorbital length & 118 \\
Craniun interorbital length & 29 \\
Internasal length & 57 \\
Prenasal length & 104 \\
Preoral length & 119 \\
Mouth width & 57 \\
Space between first gill slit & 98 \\
Space between fifth gill slit & 60 \\
Length of base of first dorsal fin & 38 \\
Height of first dorsal fin & 23 \\
Length of base of second dorsal fin & 37 \\
Height of second dorsal fin & 18 \\
Clasper outer length & 102 \\
Clasper inner length & 140 \\
Length from 15t origin to caudal apex & 107 \\
Length from ${ }^{\text {st }}$ D origin to posterior margin pelvic & 119 \\
Number of orbital thorns & 7 \\
Number of median caudal thorns & 29 \\
Number of alar thorn rows & $27 / 26$ \\
Dental formula & \\
\hline
\end{tabular}

\section{Dipturus sp.}

Three specimens were collected off Recife, Pernambuco and Natal, Rio Grande do Norte (Northeastern Brazil figure 2) by researchers of the Universidade Federal Rural de Pernambuco and according to Rosangela Lessa it is a new species and it is being described.

\section{Key to the Brazilian species of Dipturus}

1. A single nuchal thorn (Figs $3 a, 4 a) \ldots \ldots \ldots \ldots \ldots \ldots \ldots \ldots \ldots \ldots \ldots \ldots \ldots \ldots \ldots \ldots \ldots$

-. One row of nuchal thorns (Fig. 5a), or nuchal thorns entirely absent (Fig. 6a) .. 
2. Scapular thorns absent (Fig. 3a); interbranchial space smooth (Fig. 3b) without small scattered prickles; mouth width two times in preoral length; 1-3 rows of caudal thorns; anus closer to caudal apex than to snout apex ... chilensis

-. One pair of scapular thorns (Fig. 4a); interbranchial space rough with small scattered prickles (Fig. 4b); mouth width three times in preoral length; median row of disc thorns absent; anus midway between caudal space and snout apex............................... leptocauda

3. One row of nuchal thorns (Fig. 5a); three rows of caudal thorns (Fig. 5a); One row of median disc thorns present (Fig. 5a); interdorsal space present (Fig. 5 c); prickles along the whole snout (Fig. 5a); $2^{\text {nd }}$ dorsal and caudal fin bases separated by a space (Fig. 5c); dorsal surface of disc rough; interbranchial space with small scattered spines (Fig. 5b); preoral length 3,5 in disc length; adults up to $2 \mathrm{~m}$ in total length .................... trachyderma

-. Nuchal thorns absent (Fig. 6a); One row of caudal thorns (Fig. 6a); Median disc thorns absent (Fig. 6a); interdorsal space absent (Fig. 6c); prickles only on the snout apex (Fig. 6a); space between the $2^{\text {nd }}$ dorsal and caudal fin base absent (Fig. 6c); dorsal surface of disc smooth to the touch (but with very small prickles); interbranchial space without small scattered prickles (Fig. 6 b); preoral length 4,5 in the disc length; adults at the most $700 \mathrm{~mm}$ in total length ............................................

\section{CONCLUSIONS}

There are no apparent breaks in the distribution of Dipturus over the slopes. In South America, Dipturus species can be found from Northern to Southern Western Atlantic and Eastern Pacific, as seen in figure 2. Dipturus chilensis, D. trachyderma occur at least from Chile (Pacific Ocean) to Rio Grande do Sul (Atlantic Ocean). Dipturus leptocauda occurs in Rio Grande do Sul with D. chilensis and D. trachyderma. Dipturus trachyderma occurs as far as São Paulo, near Rio de Janeiro (Eastern Brazil). Dipturus teevani is the most northern species expanding the occurence from Florida (USA) to Bahia (Northeastern Brazil).

Dipturus trachyderma is the most distinct species, showing rough dorsal and ventral surfaces, and the presence of prickles along the whole snout. It is also the species which reaches the largest adult body size, attaining more than two meters in total length.

The other three species have a quite smooth skin. Dipturus chilensis and D. leptocauda share the presence of a single nuchal thorn. The former has no scapular thorns and has a smooth interbranchial space, while a pair of scapular thorns can be found in D. leptocauda (as well as the presence of interbranchial prickles). Dipturus teevani is distinct from the other three by the absence of a space between the dorsal fins, and also between the second dorsal and caudal fin. 
Tecnologia da PUC; Rio Grande do Sul); Dr. José Figueiredo (Museu de Zoologia da USP); Dr. Gustavo Nunan (Museu Nacional do Rio de Janeiro); and Gustavo Chiaramonte (Museo Argentino de Ciencias Naturales "Bernardino Rivadavia") for the loan of specimens or access to the fish collections under their care. Oceanographer Acácio Tomás (Instituto de Pesca de Santos) and Dr. Rosângela Lessa (Universidade Federal Rural de Pernambuco), for providing respectively information on two specimens of $D$. trachyderma and on the occurrence of Dipturus in Pernambuco. MSc Frieda Marti who translated papers from German articles. Dr. Paulo Brito, Biologist Hugo Santos (Universidade do Estado do Rio de Janeiro) and Dr. Gustavo Nunan, who kindly reviewed the manuscript and suggested pertinent improvements. Biologist Hugo Santos helped with the map on figure 2.

\section{REFERENCES}

Bellisio, N.B.; R.B. López \& A. Torno. 1979. Peces Marinos Patagonicos. Buenos Aires, Ministerio Economia, Secretaria Estado de Interesses Maritimos, 279p.

Bigelow, H.B. \& W.C. Schroeder. 1951. Three new skates and a new chimaerid fish from the Gulf of Mexico. Jour. Wash. Acad. Sci. 41 (12): 383-392.

1953. Fishes of the western North Atlantic. Mem. Sears Found. Mar. Res. 1: 1-558.

1965. A further account of batoid fishes from the western Atlantic. Bull. Mus. Comp. Zool. 132 (5): 445-477.

Chen, C.T. \& S.J. Joung. 1989. Fishes of the genus Raja (Rajiformes: Rajidae) from Taiwan. Jour. Taiwan Mus. 42 (2): 1-12.

Compagno, L.J.V.; D.A. Ebert \& M.J. Smale. 1989. Guide to the Sharks and Rays of South Africa. Cape Town, Struik Publ., 160p.

ESCHMEYER, W.N.; C.J. FERRARIS JR.; M.D. HOANG \& D.J. LONG. 1998. Catalog of Fishes, p. 7-958. In: W.N. ESCHMEYER (Ed.). Introductory Materials, Species of Fishes, A-L. San Francisco, California Academy Sciences, Vol. 1, 958p.

KrefFT, G. 1968. Neue und erstmalig nachgewiesene Knorpelfische aus dem Archibenthal des Südwestatlantiks, einschliesslich einer Diskussion einiger Etmopterus-Arten südlicher Meere. Arch. Fischereiwiss. 19 (1): 1-42.

KrefFt, G. \& M.D. StehmANn. 1975. Ergebnisse der Forschungereisen des FSS “Walther Herwig”, nach Südamerika. XXXVI. Zwei weitere neue Rochenarten aus dem Sudwestatlantik: Raja (Dipturus) leptocauda und Raja (Dipturus) trachyderma spec. nov. (Chondrichthyes, Batoidei, Rajidae). Arch. Fischereiwiss. 25: 77-97.

- 1987. First Records of Raja (Dipturus) trachyderma Krefft \& Stehmann, 1975 from the Southeastern Pacific off Chile, with first Descriptions of its clasper characters and additional skeletal and morphological detais (Pisces, Rajiformes, Rajidae). Stud. Neotrop. Fauna Environ. 22 (4): 169-188.

LEIBLE, M.D. 1987. Descripcíon taxonómica de juveniles y adultos de Raja (Dipturus) flavirostris Phillipi, 1892 (Rajiformes, Rajidae) capturados frente a la costa de Chile Central. Gayana 51 (1-4): 131-176.

1988. Revision de metodos para estudios taxonomicos de rayas (Rajiformes, Rajidae). Gayana Zool. 52 (1-2): 15-93.

Leible, M. \& M. Stehmann. 1987. First records of Raja (Dipturus) trachyderma Krefft \& Stehmann, 1975 from the Southeastern Pacific off Chile, with first descriptions of its clasper characters and additional skeletal and morphological details (Pisces, Rajiformes, Rajidae). Stud. Neotrop. Fauna Environ. 22 (4): 169-188.

Leible, M.D.; J. Carvajal \& M. Fuentealba. 1990. Polimorfismo en Raja (Dipturus) flavirostris Phillipi, 1892: analisis morfologica y parasitario. Bol. Soc. Biol. Concepción 61: 93-102.

MCEACHRAN, J.D. \& T. MiYAKE. 1990. Zoogeographic and Bathymetry of skates (Chondrichthyes, 
Rajoidei). In: C.H.L. Pratt JR.; T. TANiUCHI \& S.H. Gruber (Eds). Elasmobranchs as living resources advances in the biology, ecology, systematics and the status of the fisheries. NOAA Tech. Rep. Nat. Mar. Fish. Serv. 90: 285-304.

MCEACHRAN, J.D. \& K.A. DUNN. 1998. Phylogenetic analysis of skates, a morphologically conservative clade of elasmobranchs (Chondrichthyes: Rajidae). Copeia (2): 271-290.

MENNI, R.C. 1973. Rajidae del litoral bonaerense. I. Especies de los generos Raja, Bathyraja y Sympterygia (Chondrichthyes). Physis, Buenos Aires, 32: 413-439.

MenNI, R.C. \& A.E. Gosztonyı. 1977. Nuevas localidades para Raja trachyderma y Lamna nasus (Chondrichthyes, Rajidae y Lamnidae). Neotropica 23 (69): 65-68.

1982. Benthic and semidemersal fish associations in the Argentine Sea. Stud. Neotrop. Fauna Envir. 17: 1-29.

Norman, J.B. 1937. Coast fishes. Part.2. The Patagonian region. Disc. Rep. 16: 1-150.

SADOWSKY, V. 1973. Relação dos peixes cartilaginosos, p. 483-488. In: Relatório sobre a Segunda pesquisa oceanográfica e pesqueira do Atlântico Sul entre Torres e Maldonado (lat. $29^{\circ} \mathrm{S}$ $35^{\circ}$ S). Programa Rio Grande do Sul II parte 1. Governo do Rio Grande do Sul, GEDIP, IOUSP, $534 \mathrm{p}$.

SteHmann, M. 1970. Vergleichend morphologische und anatomische Untersuchungen zur Neuordnung der Systematik der nordostatlantischen Rajidae (Chondrichthyes, Batoidei). Arch. Fischereiwiss. 21: 73-164.

SteHMANN, M. \& D.L. BÜRKEL. 1984. General remarks, explanation of terms and mode of presentation for Hypotremata (Rajiformes), p. 151-152. In: P.J.P. WhiteHEAD; M.L. BAuchot; J.C. HuREAU; J. Nielsen \& E. TORTONESE (Eds). Fishes of the North-eastern Atlantic and the Mediterranean. Paris, UNESCO, Vol. 1, 683p.

Uyeno, T. \& T. Miyake. 1983. Rajidae, p. 73-78. In: T. Uyeno; K. Matsuura \& E. FujII (Eds). Fishes Trawled off Suriname and French Guiana. Tokio, Japan Marine Fishery Resource Center, 519p. Vooren, C.M. 1997. Demersal Elasmobranchs, p. 141-146. In: U. SEelinger; C. Odebrecht \& J.P. CASTELLO (Eds). Subtropical convergence environments: the coast and sea in the southwestern Atlantic. Berlin, Springer-Verlag, 341p.

Recebido em 02.III.2000; aceito em 05.IV.2001. 